UDC 339.92

JEL F01, O19

DOI 10.31375/2226-1915-2019-1-5-16
Zhang Hong

Senior Fellow In Institute Russian, East Europe \& Central Asia Studies, Chinese Academy of Social Sciences, Beijing, China ORCID https://orcid.org/0000-0001-7348-1042 e-mail: hongzhang@cass.org.cn

\title{
CHINA-UKRAINE ECONOMIC COOPERATION IN A CHANGING WORLD: THE CURRENT SITUATION AND PROPOSALS
}

\begin{abstract}
This paper mainly discusses current situation and problems in ChinaUkraine economic cooperation. Tasks of research - analyze the external challenges of economic cooperation between China and Ukraine, and find a win-win cooperation model. First, the uncertainty of the international economic order will affects Ukraine's economic growth. The US-China trade war will affect the export of agricultural products and metallurgical products in Ukraine and delay the recovery of the Ukrainian economy. The conflict in Ukraine's Donbass and Brexit will worsen the external economic environment of Ukraine. Secondly, we point out that Ukraine didn't share China's opportunities and was overtaken by other post-Soviet countries. Third, we proposed that speed up FTA negotiations is key to enhancing the quality of economic cooperation, attract Chinese investment.
\end{abstract}

Keywords: China, Ukraine, world power, economic cooperation, international economic order.

УДК 339.92

JEL F01, 019

DOI 10.31375/2226-1915-2019-1-5-16
ЖАНГ ХОНГ

Старший науковий співробітник Інституту Російської, Східної Європи та Центральної Азії, Китайська академія соціальних наук, Пекін, Китай ORCID https://orcid.org/0000-0001-7348-1042 e-mail: hongzhang@cass.org.cn

\section{ЕКОНОМІЧНЕ СПІВРОБІТНИЦТВО КИТАЙ-УКРАЇНА В МІНЛИВОМУ СВІТІ: СУЧАСНА СИТУАЦІЯ ТА ПРОПОЗИЦІї}

Анотація. У даній статті передусім вказується поточна ситуація $i$ проблеми в економічному співробітництві між Китаєм і Україною. Метою дослідження є аналіз зовнішніх викликів економічного співробітництва між Китаєм $i$ Украӥною і пошук безпрограшну модель співпраці.

По-перше, невизначеність міжнародного економічного порядку впливає на економічне зростання Украӥни. Торговельна війна між США і Китаєм впливає на експорт сільськогосподарської та металургійної продукиії. Конфлікт в Украӥні на Донбасі і Брексит погіршує зовнішньоекономічне середовище України.

По-друге, ми відзначаємо, щуо Украӥна не використала можливості для співпрачі з Китаєм, і ї̈ обігнали інші пострадянські краӥни.

$\overline{\text { (C) Жанг Хонг, } 2019}$ 
DEVELOPMENT OF MANAGEMENT

AND ENTREPRENEURSHIP METHODS ON TRANSPORT, № 1(66), 2019
РОЗВИТОК МЕТОДІВ

УПРАВЛІННЯ ТА ГОСПОДАРЮВАННЯ

НА ТРАНСПОРТІ, № 1(66), 2019

Побудова безперервного спілкування, консультаиійних каналів і механізмів, а також більш ефективне підключення відповідних ресурсів дозволить своєчасно вирімувати проблеми і труднощі при плануванні та реалізації спільних проектів. Вважається, що прискорення переговорів про вільну торгівлю $є$ ключем до підвищення якості економічного співробітництва, залученню китайських інвестииій.

По-третє, є перспективний напрямок, що буде сприяти співробітництву великих підприємств між Украӥною і Китаєм. Автор рекомендує великим підприємствам забезпечити більи стабільні відносини для обох сторін з освоєння нових ринків для досягнення довгострокового, стратегічно важливого взаємовигідного партнерства.

Ключові слова: Китай, Україна, світова держава, економічне співробітництво, міжнародний економічний порядок.

УДК 339.92

JEL F01, O19

DOI 10.31375/2226-1915-2019-1-5-16
ЖАНГ ХОНГ

Старший научный сотрудник Института Российской, Восточной Европы и Центральной Азии, Китайская академия социальных наук, Пекин, Китай

\section{ЭКОНОМИЧЕСКОЕ СОТРУДНИЧЕСТВО КИТАЙ-УКРАИНА В МЕНЯЮЩЕМСЯ МИРЕ: СОВРЕМЕННАЯ СИТУАЦИЯ И ПРЕДЛОЖЕНИЯ}

Аннотация. В данной статье прежде всего указывается текущая ситуаиия и проблемы в экономическом сотрудничестве между Китаем и Украиной. Целью исследования является анализ внешних вызовов экономического сотрудничества между Китаем и Украиной и поиск беспроигрышной модели сотрудничества.

Во-первых, неопределенность международного экономического порядка влияет на экономический рост Украины. Торговая война между США и Китаем влияет на экспорт сельскохозяйственной и металлургической продукичи. Конфликт в Украине на Донбассе и Брексит ухудшает внешнеэкономическую среду Украины.

Во-вторых, мы отмечаем, что Украина не использовала возможности для сотрудничества с Китаем, и ее обогнали другие постсоветские страны. Построение непрерывного общения, консультационных каналов и механизмов, а также более эффективное подключение соответствующих ресурсов позволит своевременно решать проблемы и трудности при планировании и реализачии совместных проектов. Считается, что ускорение переговоров о свободной торговле является ключом к повышению качества экономического сотрудничества, привлечению китайских инвестиций. В-третьих, существует перспективное направление, которое будет способствовать сотрудничеству крупных предприятий между Украиной и Китаем. Автор рекомендует крупным предприятиям обеспечить более стабильные отношения для обеих сторон по освоению новых рынков для достижения долгосрочного, стратегически важного взаимовыгодного партнерства.

Ключевые слова: Китай, Украина, мировая держава, экономическое сотрудничество, международный экономический порядок. 
Problem statement. Previous studies on economic cooperation between China and Ukraine mainly focused on micro-level issues, and paid little attention to the external macrointernational environment. The author believes that in the world of economic globalization and political multipolarity, the external macro-environment has become an area that we can not ignore. There are at least three challenges involved: the traditional international trade system is increasingly being questioned; European integration is being challenged; and the contradiction of economic cooperation in post-Soviet countries. The free trade agreement signed by Ukraine and the EU has greatly inspired China. The EU provides a longterm and stable institutional basis for economic cooperation between the two sides through the institutional arrangements of the associated country agreements. There are many reasons for the slow development of economic cooperation between China and Ukraine, including not only geographical factors, economic structure factors, market size factors, but also many deficiencies of economic cooperation system. We believe that the institutional construction of economic cooperation should be one of the priority directions of the two countries in the construction of «one belt and one road». We can overcome the cooperation instability caused by the change of leaders and the government by advan-cing the FTA. By promoting the mo-dernization of the cooperation system, we can not only increase the stability of economic cooperation between China and Ukraine, but also help to improve the transparency and openness of cooperation, increase cooperation between China and other economies in Ukraine, overcome market fluctuations and share opportunities for development.

Review of the last research and publications. The issues of economic cooperation between Ukraine and China are reflected in the works of such scholars as: Z.Ya. Shcherbataya, A.A. Volovich, V. Balandin, V. Karpusov, P.M. Mosias, I. Pogorelova, V. Kiktenko, Andrey Goncharuk, etc. The work of these scientists largely describes the scientific, technical, humanitarian, aerospace cooperation of Ukraine with China and military cooperation. These scholars focus their research on bilateral economic relations, rarely on changes in the international order, especially since Trump came to power, and seldom discuss the external challenges of economic cooperation between the two countries.

Tasks of research. Analyze the external challenges of economic cooperation between China and Ukraine, and find a win-win cooperation model.

The basic material of research. This paper uses the theory of international political economy as the main research method to analyze the external environment of economic cooperation between China and Ukraine. The author believes that in the current international economic order, Ukraine can overcome the uncertainty of external economic environment and internal economic challenges by reaching more FTA institutional arrangements with major economies, including China. 


\section{THREE CHANGES OF INTERNATIONAL ENVIRONMENT}

\section{Trump impacts upon international trade order}

As we all know, for many years international community rely on the multilateral international order, both in the economic field and in terms of security. In the post-Cold War era, Trump rapidly transitioned from multilateralism to unilateralism, although most of American believed in. Once the multilateralism is destroyed, it is not possible to form the order. International community insists that negotiations are best carried out and disputes settled through a rules-based system. Introducing trade barriers on a tit-for-tat basis potentially harm companies on both sides.

The US has been preventing vacancies in the seven-member Appellate Body from being filled for almost two years, which has affected its functioning even as disputes continue to pile up. "The move goes against the tenet of multilateralism, which we have been try-ing to strengthen. Trump has repeatedly criticized many international trade ag-reements such as the WTO and the North American Free Trade Agreement (NAFTA). He believes that these are not conducive to the United States in resol-ving international trade disputes».

Trump is adhering to the "America First» and he prefers to use direct negotiations or initiate punitive tariffs. The essence of the Trump administration trade negotiations is that they do not intend to use the WTO and its procedures at all, and choose to bypass inter-national institutions and adopt unilateral measures. This would lead to tremen-dous uncertainty in the global economy. All countries would be affected some economists are predicting the tension in U.S.-China trade relations could conti-nue for an extended period of time. A top economist, however, says the prob-lem with U.S. trade deficits is «multi-lateral». Derek Scissors, Asia economist at the American Enterprise Institute said. "The president likes to pick trade fights», Beyond America's ongoing trade fight with China, Trump also suggested to a Wall Street Journal columnist on Thursday that Japan could be next in his sights. Model of International order is changing from ringtone to vibrate.

\section{Geopolitical uncertainty in Europe}

After the crisis in Ukraine, it's continued tension in relations between Russia and NATO, although Trump appreciate each other with Putin, but the two sides escalating sanctions, restart the arms race in Europe, the security pressure risein Central and Eastern Europe. The pressure of the arms race will lead to a deterioration of the geopolitical environment. In fact, the United States and Europe on the issue of NATO is not large differences, with the European countries to increase military spending, Ukraine's security environment will become tenser. Stable geopolitical environment is a necessary condition for economic cooperation and an important factor in Ukraine's economic recovery impact.

\section{US interest rate hike and the US tax cuts have brought financial pressure to developing countries}


Given that the current and nearterm economic prospects of the United States are relatively stable, the Fed rate hike process will progress as planned as or even faster than planned.

As the Fed lifted rates in this year, it added momentum to a steady stream of money that has been abandoning emerging markets and flowing toward U.S. shores. With further Fed increases expected this year, developing countries are bracing for additional impacts: more investment departing, more currencies falling, more economies weakening.

\section{Danger of non-agreement Brexit}

European Union countries will suffer long-term damage equivalent to about $1,5 \%$ of annual economic output if Britain leaves the bloc without a free trade deal next year, the International Monetary Fund said. «The strength of the euro area-UK integration implies that there would be no Brexit winners», the IMF said. The EU's lost economic output in the case of no deal would cost the bloc around $\$ 250$ billion, according to Reuters calculations based on the IMF's estimate of the size of the EU economy excluding Britain this year. Now, The European Commission predicts that growth in the $\mathrm{EU}$ is $2,1 \%$ in 2018 , compared with $2,3 \%$ in the commission's spring forecast and $2,4 \%$ in 2017. Its forecast was unchanged for growth $2 \%$ in 2019.

According to research group Oxford Economics. That Hard Brexit could cost EU economy $£ 100 \mathrm{bn}$. A no-deal Brexit could cost the remaining 27 EU countries $£ 99,5$ bn in lost trade by 2020 . The report said although the effects would be «far from disastrous» for the EU as a whole because it has a larger economy compared to the UK, Germany would be the particularly exposed to a supply chain shock, as its firms account for around $18 \%$ of goods used by European companies in the motor industry - the EU's largest export to the UK.

The OECD estimated before the referendum that a WTO Brexit could cost the UK up to $5,1 \%$ of GDP over 15 years. A study by the London School of Economics estimated a 9,5\% hit. And the government's own leaked internal analysis of WTO Brexit estimated a GDP loss of up to $10,3 \%$.

\section{THE IMPACT OF CHANGES IN INTERNATIONAL ORDER ON THE ECONOMIC RELATIONS BETWEEN CHINA AND UKRAINE}

If the two sides cannot reach a compromise within a short period of time, China's economic growth rate will be affected. According to Professor Li Daokui of Tsinghua University, China's economic growth will slow down by $0,3 \%$, affecting the decline in global commodity prices, which is not good news for Ukraine. "We used a mathematical model to calculate the negative impact of the trade war. It is not very large, it is not significant. It is less than half a percent (of an) impact to the Chinese economy», Zhou told CNBC's Steve Sedgwick at the Ambrosetti Forum on the shores of Lake Como in Italy. The trade war will prompt China to increase the construction of the Belt and Road. In order to make up for the impact of the CHINA-US trade question on the Chinese economy, China is likely to increase the initiative of the Belt and Road Initiative and expand investment with countries along the route. By 
exporting capital and technology, we will drive Chinese products to the world. Continued expansion of investment and infrastructure cooperation in the Belt and Road region may be an opportunity for Ukraine.

The CHINA-US trade war will increase the chances of exporting agricultural products of other countries to China. Corn and soybeans are alternative in the feed mill industry, after the US raise Chinese soy import tariffs, the price advantage of corn has increased. The trade war will prompt China to further expand its opening to the outside world. Not only can US agricultural products and energy products be restricted to enter the Chinese market, but the opportunities for other countries to export agricultural products to China will increase. Among them, Ukrainian agri-cultural products have gained more mar-ket opportunities, and Ukrainian corn, wheat and Sunflower oil are likely to expand exports to China.

\section{CURRENT SITUATION AND ISSUES OF THE ECONOMICS COOPERATION BETWEEN CHINA AND UKRAINE}

The quantity of certification of Ukrainian agricultural products in China lags far behind other countries of the former Soviet Union. Policy communication is an important guarantee for the construction of the «Belt and Road», and is also the fundamental prerequisite for mutually beneficial countries along the route. To further promote the policy communication in the construction of the «Belt and Road», on the one hand, we need the support from the cultural selfness; on the other hand, there must be a long-term policy communication mechanism as a safeguard measure. Building smooth communication, consultation channels and mechanisms, and more effectively connect relevant resources to solve problems and difficulties in planning implementation and project execution in a timely manner. Comparing the trade in agricultural products between the former Soviet Union and China, we can find that Russia, Belarus and Kazakhstan have already taken the lead, and cooperation at the governmental level has favorably contributed to the rapid growth of exports to China.

Russia: In January 2016, Russian wheat, soybeans, corn, rice, rapeseed and Kazakhstan wheat were allowed to enter the Chinese market. In 2016, China has become a major consumer of Russian food, buying a total of $\$ 1,55$ billion worth of food in Russia. In terms of currency, this is an increase of $19,5 \%$ over the previous year. China imported more than $\$ 3$ billion in agricultural products from Russia in 2017. According to statistics from the General Administration of Customs of China, the total trade volume between China and Russia reached 31,2 billion US dollars in the first four months of this year, a yearon-year increase of nearly $30 \%$. It is worth noting that Russia's exports of agricultural products to China increased by $35,3 \%$ in the first four months. Demetri Avelizov, head of the Analytical Center of the Russian Ministry of Agriculture said that Russia plans to increase exports of agricultural products to China from US $\$ 1,8$ billion to US $\$ 9,5$ billion by 2024 . ${ }^{1}$

1 俄计划至2024年将对华农产品出口提高 到95亿美元俄罗斯卫星通讯社叶卡捷琳堡 
Kazakhstan: The plan is to substantially increase the export of goods to China. In 2017, the export volume of agricultural products to China increased by $34,3 \%$. ${ }^{2}$ In May 2018 , the two sides held consultations on deepening CHINA-Kazakhstan relations and acti-vely developing bilateral trade relations under the framework of the «Belt and Road» initiative. Kazakhstan plans to reach an agreement with the Chinese side on animal and plant quarantine requirements for beef, barley, corn, beans and melon. On May 15th, Kazakhstan's Prime Minister Bakhtjan Sakintaev said in a joint meeting of the upper and lower houses of the parliament that Kazakhstan has the ability to increase its exports of agricultural pro-ducts from the current US\$150 million to US\$1 billion. In fact, Kazakhstan is more successful in developing China's agricultural market. in 2018 Kazakhstan doubles agricultural exports to China. China opened for numerous agricultural products (fish products, thoroughbred horses, frozen mutton, honey, wheat middling, soybeans, horses for slaughter, canola meal, beef, Alfalfa hay, flour, vegetable oil, barley, corn", said Vice Minister of Agriculture Arman Yevniyev. ${ }^{3}$

Belarus: In September 2016, China and Belarus signed an agreement

2018年7月11日电，http://sputniknews.cn/e conomics/201807111025857081/

2 Export of agricultural goods to China increased in 2017, KazTAG, https:// www. kaztag.kz/en/news/export-of-agriculturalgoods-to-china-increased-in-2017.

${ }^{3}$ Kazakhstan doubles agricultural exports to China, KAZINFORM https:// www. inform.kz/en/kazakhstan-doublesagricultural-exports-to-china_a3473766 on the inspection and quarantine of Chinese white beef; in July 2017, the two sides signed an official document, Belarus frozen beef products officially pas-sed the quarantine of China; in Decem-ber 2017, 2 Belarusian meat producers were approved to register in China. In 2017, Belarus was the first country in the Commonwealth of Independent Sta-tes to be allowed to supply beef to the Chinese market. The active operation of the Belarusian government has led to a rapid increase in the export of agricul-tural products to China. In 2018, the total supply of agricultural products in China and Belarus reached US\$114 mil-lion. According to a forecast report of the Belarus Government, Belarus's ex-ports of goods to China in 2018 will increase by $44 \%$ compared with last year.

There are issues on the enterprise marketing means.

Ukrainian enterprises in the development of the Chinese market there are also some problems, such as marke-ting, back, market research is not deep enough.

In the countries of the former Soviet Union, traditional foods are chocolate, for example.

Russian products sell well in the Chinese market, and Ukrainian products are weak. Ukrainian researchers do not think about successful cases, but instead blame the tastes of consumers.

Vyacheslav Lysenko from Retailers.ua believed that Roshen confectionery products are not popular in the Chinese market, because. Chinese people do not like sweet sweets and chocolate.

Chocolate has a huge market in China, with annual consumption. Ukrainian chocolate has similar taste and pa- 
ckaging to Russian chocolate, and Russian chocolate with similar taste is popular in China. (Russian Satellite News Agency Moscow, May 4, 2018) The total export volume of Russian chocolate confectionery products increased by $45 \%$ compared with last year, reaching US\$82 million. The supply reached 29,000 tons. ${ }^{4}$ The main products exported from Russia are cereals, fish and seafood, confectionery products and Vegetable oils. In China, almost 20 percent of chocolate sold by the electricity supplier way, and in the United States, Britain, France and other regions, account for its chocolate online only by less than $5 \%{ }^{5}$ The development of the Chinese econo-my has made the chocolate market a serious differentiation. In the current market of chocolate, ultra-elite and high-quality products have become a new en-gine of market growth. Therefore, in re-cent years, popular brands of chocolate, such as Hershey and Nestle, are contri-buting to the elite market. Now, the annual consumption of chocolate per capi-ta in China is only 200 grams.

If the annual consumption of chocolate in China per capita reaches 1 kilogram, it will become the world's largest chocolate market. Therefore, some experts predict that by 2020 China's chocolate market will reach 6 billion US dollars.

\footnotetext{
${ }^{4}$ Китай лидирует по закупкам шоколадных конфет из РФ, «Вести. Экономика», https:// www. vestifinance. ru/ articles/ 101033

5 陈泽秀: 为什么巧克力在 中国不好卖了 ? 财经网2017年2月24日，http://www. caijing.com.cn/
}

\section{DEVELOPMENT PROSPECT OF IMPORTING MARKET IN CHINA}

In the Chinese market there are huge opportunities, and the volume of agricultural imports is growing rapidly. The total volume of trade in agricultural products in China increased from 11,85 billion dollars in 2001 to 116,88 billion dollars. In 2015, an increase of 8,9 times and an average annual growth rate of $17,8 \%$. In 2017, imports of agricultural products in China amounted to 125,86 billion dollars, an increase of 14,29 billion dollars over last year, and an increase of $12,8 \%{ }^{6}$

The whole story of Chinese food imports ultimately comes back to a poorly anticipated rise in consumer demand. According to the World Bank, Chinese average daily calorific intake has increased from 2,163 to 3,036 per person between 1980 and 2009 . $^{7}$

Yet behind these numbers lies an even larger increase in what is known as 'cereal equivalent' - meaning the amount of cereals used to produce the calories - which has more than doubled over the same period, due to the increase in chicken, pork and beef production from 20 million tonnes in 1986 to 70 million tonnes in 2012 .

\section{6 进口稳步增长优化我国农产品供给结}

构,《经济日报》2018年5月18日。http:// www.gov.cn/zhengce/2018-05/21/ content_ 5292354.htm

${ }^{7}$ Emiko Fukase and Will Martin, Who Will Feed China in the 21st Century? Income Growth and Food Demand and Supply in China, Policy Research Working Paper 6926 of The World Bank. https:// openknowledge.worldbank.org/handle/10986/18808 


\section{THREE ASPECTS OF WORK NEEDED TO IMPROVE CHINA-UKRAINE ECONOMIC RELATIONS}

Firstly, it is hoped that to strengthen political docking through comprehensive economic and trade negotiations.

Ukraine has been reforming the market for more than 20 years. The level of enterprise management and market development is still limited, and it is difficult to compete with large European and American companies. In the process of opening the Chinese market, we must rely on government support. A huge Chinese market, but not so easy to get a chance, we must create a government business open, friendly business environment. At present, China and Ukraine have signed a number of agricultural products, although the speed of inspection and quarantine agreement, but the implementation is slow. Ukraine's trade policy towards China lacks integrity, lack of continuity in the process of bilateral communication. If these two countries can begin negotiations on an agreement on free trade and investment protection agreement to promote the export of agricultural products of Ukraine to China through the integrity of the mechanisms.

Secondly, it is hoped that to improve the investment environment in Ukraine. After the 2014 crisis in Ukraine, the new government of Ukraine has had a tough fiscal reform and anti-corruption reform. But effect of the reform is still not satisfactory. We support EU efforts to improve the political and economic environment in Ukraine. For now, it is a very difficult task that promotes anti-corruption reform in Ukraine. And The EU assist Ukraine in improving the anti-corruption level may deserve admiration.

The slow progress of the Ukrainian reform is the main reason for the slow receipt of foreign investment. Ukraine has a superior geographical position and has good market prospects in infrastructure and agriculture. However, due to the delay in the implementation of relevant policies, the slow progress of the Law Land and privatization has led to stagnant foreign investment.

Thirdly, it is hoped that to promote large enterprises cooperation between Ukraine and China. At present, Ukrainian enterprises are characterized by a limited scale, lack of investment and technical force. Therefore, it will inevitably be difficult to develop the Chinese market.

On the Chinese market, in addition to state support, the choice of business partners is especially important. Many Chinese companies also want to enter the infrastructure and production in Ukraine.

Therefore, we recommend the large enterprises a butt way to provide a more stable relationship for both companies to develop new markets in order to achieve a long-term mutually beneficial partnership built only complementary and strategic importance. 

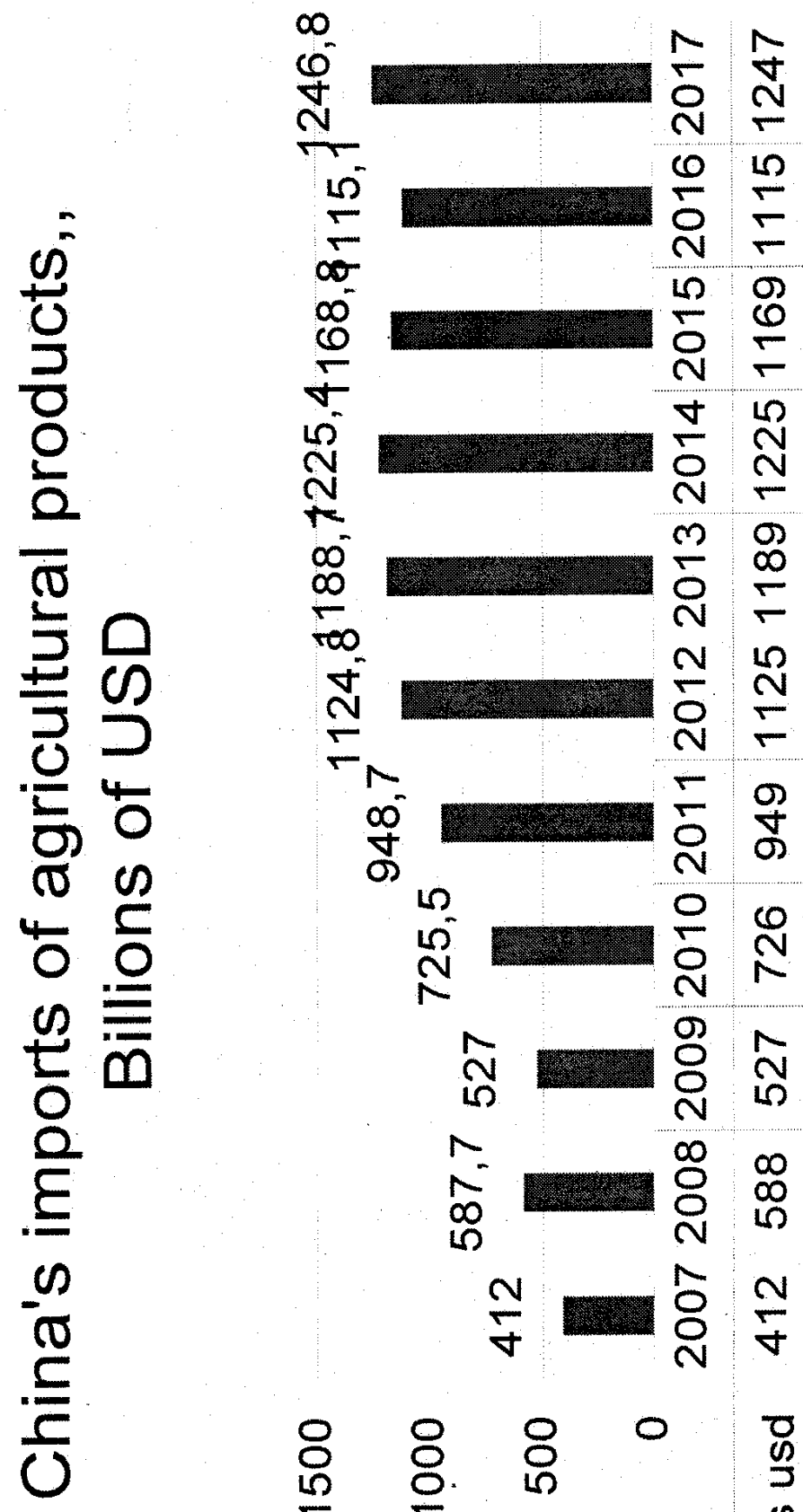

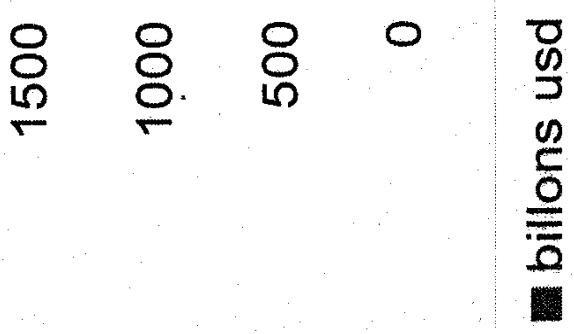

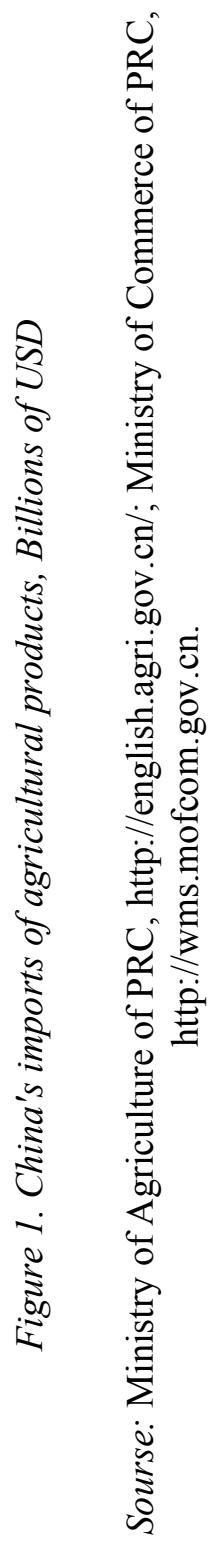




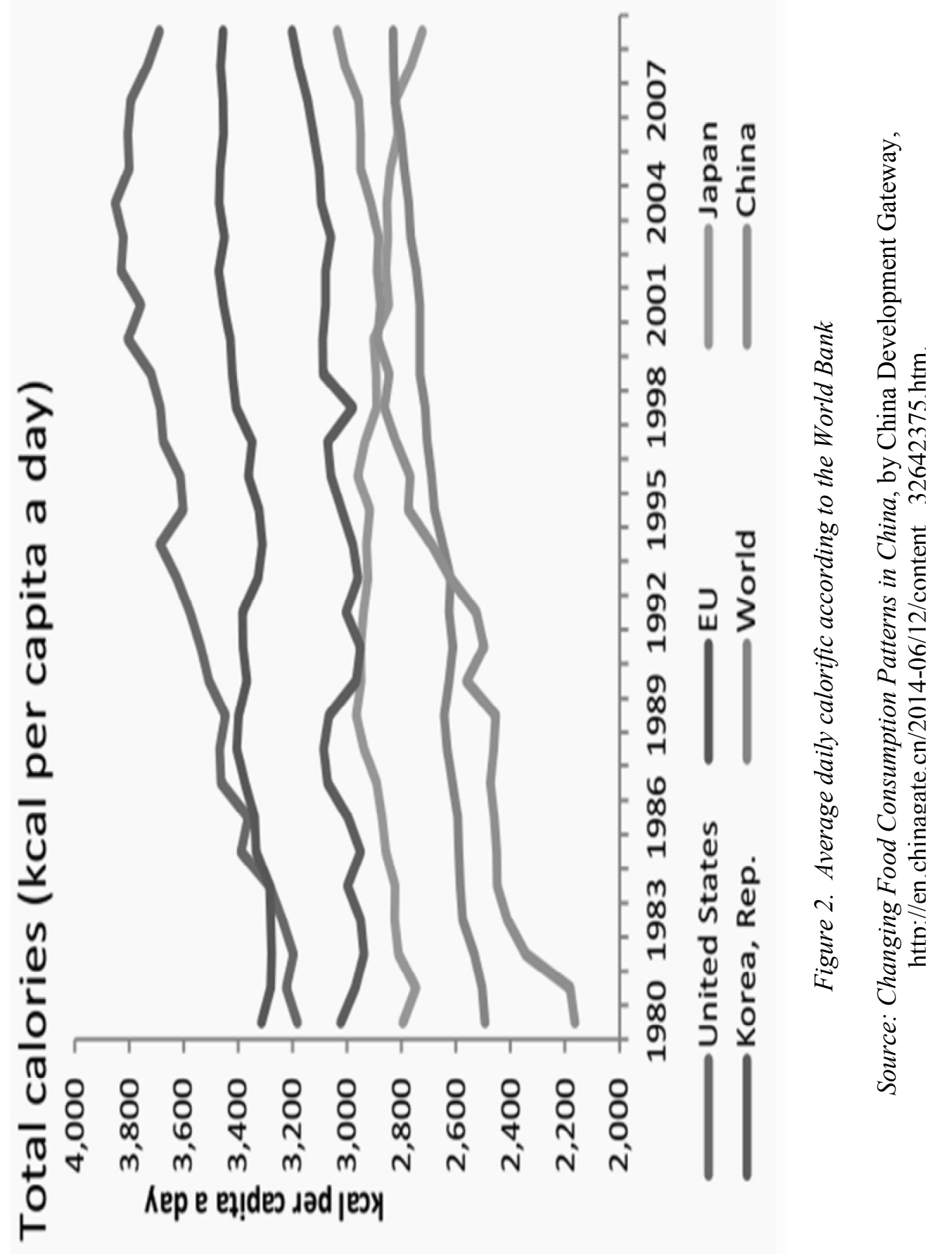




\section{CONCLUSIONS}

Changes in the international political and economic order are not only opportunities, but also challenges. Despite the many difficulties, both China and Ukraine recognize the political and economic interests of developing economic cooperation. Ukraine is an important partner of China in Eastern Europe. China is one of the indispensable mar- kets for Ukraine to participate in economic globalization. Accelerating the FTA may be one of the means by which we overcome difficulties and is an option for us to adjust to the international order. Opening FTA negotiations is a long and complex task, which depends not only on the political mutual trust between the two countries, but also on a friendly international environment.

\section{REFERENCES}

1. Emiko, Fukase \& Will, Martin (2016). Who Will Feed China in the 21st Century? Income Growth and Food Demand and Supply in China. Journal of Agricultural Economics 67(1).

2. World Bank and the Development Research Centre (DRC) of State Council, China's Urbanization and Food Security, (World Bank and DRC, Washington DC and Beijing, 2014).

3. Kucherov, N. (2018). Китайская экспансия vs украинская коррупция [Chinese expansion vs Ukrainian corruption]. Информационноаналитическое издание «Одна Родина» - Information and analytical publication «One Mother-land». Retrieved from: https://odnarodyna.org/content/kitayskaya-ekspansiya-vs-ukrainskayakorrupciya.

4. JOURNAL «UKRAINE-CHINA», chief editor by V. Kiktenko, №14, 2018.

5. JOURNAL «UKRAINE-CHINA», chief editor by V. Kiktenko, №13, 2018.

6. Olena Mykal, Why China Is Interested in Ukraine, THE DIPLOMAT. Retrieved from: https://thediplomat.com/2016/03/why-china-is-interested-inukrainel

7. Pochtovyuk, A. \& Semenikhina, V. (2017). Business relations between Ukraine and China:development options, SHS Web of Conferences 39, 01022 .

8. The World Bank [online] (2017). Retrieved from: https:// data. worldbank. org/country/china

Article received 23.01.2019

Reference a JournalArtic: Zhang Hong (2019). China-Ukraine economic cooperation in a changing world: the current situation and proposals. Development of management and entrepreneurship methods on transport, 5-16. DOI: 10.31375/22261915-2019-1-5-16. 